\title{
Cry, the beloved country ...
}

Towards the end of last year (2016), around 1300 psychiatric patients were moved over a period of several months from Life Esidimeni, a specialised private facility, to care homes run by charities. Esidimeni means 'place of dignity', and the private company delivers healthcare services to indigent patients under contract to national and provincial departments of health and social development, and has done for five decades. The end result reverberated around the country, and indeed the world - at least 100 deaths in truly appalling circumstances.

The moves were made in the face of appeals by family members, psychologists and advocacy groups that this would be dangerous for patients. They pleaded with Qedani Mahlangu, then Gauteng provincial health minister, to stop the move. They even went to court. The move went ahead. Mahlangu has resigned - an unusual move among South African politicians - but too little, too late.

As Dan Stein and colleagues ${ }^{[1]}$ point out so well in this issue of the $S A M J$, this is 'death by maladministration'. The patients were moved to NGOs that 'jostled' over which patients they wanted in what the health ombudsman's report described as a 'cattle auction. ${ }^{\text {'2] }}$ Some sent pick-up trucks to collect them. Patients essentially died of neglect. These people are the 'vulnerable and voiceless' in society that Stein et al. rightly describe as serving as the 'canary in the coal mine'.

That they died at all is more than shocking. It is reminiscent of what was quietly happening in Nazi Germany in the late 1930s under Hitler's regime. It reflects a growing lack of concern worldwide for people who cannot speak for themselves, be they the mentally ill, the elderly and frail, or the refugees who are being hounded around Europe because, quite simply, no one wants them.

What is particularly distressing about this tragedy is that people tried to cover it up. The risks were known before the patients were moved, and Mahlangu and her administration simply watched as the tragedy unfolded. Mahlangu only admitted to the deaths after being quizzed by the shadow minister for health in Parliament - at the time the death toll stood at 77. Patients were dying even as Parliament heard of the debacle. Esidimeni was ignored during the chaotic State of the Nation address, except by one DA MP who unsuccessfully called for a minute's silence to honour the dead. In the past week, our deputy president and minister of health have been doing some fancy footwork in the name of damage limitation - cynically, this appears to be more about saving face than saving lives. So far, it appears that 27 psychiatric patients have been moved, with the consent of their families, to the Solomon Stix Morewa Private Hospital in Johannesburg. ${ }^{[3]}$ But since there is little or no public knowledge of the fates of the rest of the patients who were moved, it is possible that there are still patients at risk of neglect in unsuitable, but cheap, NGO facilities.

The 'canary in the coal mine' analogy is apt. We can no longer close our eyes to the corruption and wilful neglect of our public services, and indeed our people, by a government that is increasingly desperate to hold on to power, and through it access to the public purse. The imminent crisis around the distribution of social grants on 1 April this year is another case in point. If this distribution fails, lack of these grants will cause massive hardship, and quite possibly illness and death, for yet another group of voiceless and vulnerable people.

Across the world, humanity is losing its compassion. The events around refugees and asylum seekers in Europe are one example. The hate speech and crimes that are increasing in the UK (and other parts of Europe) and the USA with the rise of the far right are another. Greed and selfishness are becoming acceptable. We must not let this happen.

\section{Bridget Farham \\ Editor \\ ugqirha@iafrica.com}

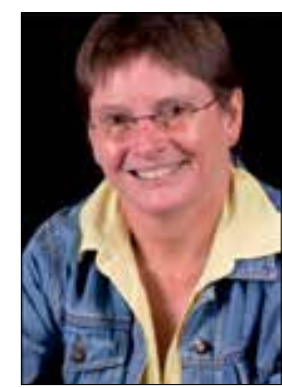

1. Stein DJ, Chambers C, Daniels I, et al. Death by maladministration: An important category of patien mortality. S Afr Med J 2017;107(4):280. https://doi.org/10.7196/SAMJ.2017.v107i4.12389

2. Makgoba MW. The report into the 'circumstances surrounding the deaths of mentially ill patients Gauteng Province. 2017. http://politicsweb.co.za/documents/the-life-esidimeni-disaster-the-makgobareport (accessed 13 March 2017)

3. Eye Witness News. Motsoaledi confirms move of Esidimeni patients to other facilities. http://ewn co.za/2017/03/03/motsoaledi-confirms-move-of-esidimeni-patients-to-other-facilities (accessed 13 March 2017)

S Afr Med J 2017;107(4):277. DOI:10.7196/SAMJ.2017.v107i4.12460 